\title{
THE TRANSLATABILITY OF COMPOUND WORDS IN THE HUNGER GAMES IN ENGLISH AND INDONESIAN
}

\author{
Dwi Apcita Estorina ${ }^{1}$, Ikmi Nur Oktavianti \\ ${ }^{1}$ University of Ahmad Dahlan \\ 1chita1995@gmail.com \\ ${ }^{2}$ University of Ahmad Dahlan
}

\begin{abstract}
English is used as a foreign language in some countries since it is one of international languages. In Indonesia, English is not the mother tongue of the majority of occupants, so the translation is needed to solve the communication problem between two different languages. This research entitled "The Translatability of Compound Words in The Hunger Games in English and Indonesian Versions" is intended to find out the English compound words equivalently translatable into Indonesian found in the novel and to describe the causes of the non-equivalent translation.

This research belongs to descriptive qualitative research as the research design. The research object of this research is compound and the data of this research is the compound words of English language and Indonesian language. As for the data source, The Hunger Games novel is used as the data source of the research. In collecting the data, the researcher uses observing method. In observing method, the researcher reads, underlines, and transcribes the compound words of English and Indonesian language found in the novel. In data analysis, the researcher identifies the data based on English language and Indonesian language compound words.

The analysis of the research shows that there are English compound words that can be equivalently translatable into Indonesian and some cannot. The non-equivalent translation of the compounds has the highest frequency that is 29 cases. It happens because the translator translated the English compound words into words and phrases. The frequency of equivalent translation is 21 cases in which the translator translated the English compound words into Indonesian compound. As for the causes, there are some factors triggering the inability to translate equivalently and one of the most influencing ones is cultural aspect.
\end{abstract}

Keywords: translatability, equivalence, compound

\section{INTRODUCTION}

English is known as one of the international languages being spoken by people for economic, educational, recreational activities, etc. As an international language, it is being used to write whether for scientific or fictional works for instance textbooks, novels, magazines, newspapers, etc. On the other side, not every people has capabilities of speaking, writing, listening, or reading English literatures. Thus, translation is needed to solve the linguistic gap between source language (SL) and target language (TL). According to Catford (1965:20), the definition of translation is "the replacement of textual material in one language (SL) by equivalent textual material in another language (TL)". SL is symbol of Source Language, and TL is symbol of Target Language. In the other word, translation can be defined as the process of changing the same meaning with an equivalent meaning from the source language into the target language. In addition, Nida and Taber (1982: 12) state that "translation consists of reproducing in the receptor language the closest natural equivalent of the source language message, first in terms of meaning and secondly in terms of style". Translating activities result in works for example the Indonesian 
version of the Hunger Games novel which the writer is about to discuss in context of word translatability between the translation and the original (English) version.

Translations by the translators cannot be defined as perfect for every case. Hereby, the writer would like to find the equivalence of words in SL and TL. One of word forms is compound word. Compound word is a word that is made up of two or more independent words whose meanings are often different when the base words stand independently. Studies about translatability of compound words haven't been extensively examined. In translating, some terms are usually being heard and of which one of them is translatability. Translatability is a condition in which the terms are able to be translated into the target language or not. So far, researchers are still looking for topics related to translatability of compound words in the novel The Hunger Games in English and Indonesian versions, until the recent times, researcher is not able to find it. But, there is a bunch of studies related to this research, such as the research on analysis of translation shift of two versions of a novel (Purwanti, 2012; Noviana, 2012), translation shift in the movie text (Purwarahardi, 2014; Kantiastuti, 2014), and translation shift in movie subtitle (Sunarto, 2015; Arif, 2015). Because of the limited studies on translatability of compound words, the researcher is interesting to conduct this research. The writer would like to examine whether there is equivalence of the translation of compounds in SL and the counterparts in the translated form in TL.

\section{WHAT IS TRANSLATION?}

Translation is the process of transfer the message or information from SL to TL, which the message or information in TL should has the equivalence and closely meaning with the SL conducted by a translator. Nida and Taber (1982:12) explain that "translation consists in reproducing in the receptor language the closest natural equivalent of the source language message, first in terms of meaning and secondly in terms of style". Also, Munday (as cited in Herman, 2014) says that "the term translation itself has several meanings: it can refer to the product involves the translated text and the process involves the translator changing an original source language into target language in different verbal language". There are three kinds of equivalence in translation following Newmark's (1988) ideas, namely cultural equivalent is an approximate translation where a SL cultural word is translated by a TL cultural word; functional equivalent applied to cultural words, requires the use of a culture-free word, sometimes with a new specific term; and descriptive equivalent, in translation description sometimes has to be weighed against function.

\section{METHODS}

This is a descriptive qualitative research. It belongs to qualitative research as it is framed in terms of using words (qualitative) rather than numbers (quantitative), or using closed-ended questions (quantitative hypotheses) rather than open-ended questions (qualitative interview questions) (Creswell, 2014: 32)". The data of this research are compound word of English language and Indonesian language. The data of this research were taken from the novel written by Suzanne Collins entitled The Hunger Games. The data were collected by observing The Hunger Games novel by reading and identifying the data based on English language and Indonesian language compound words. To analyze the data, this research was conducted by using identity method and distributional method because it focuses on the language structure and language meaning. 


\section{FINDINGS AND DISCUSSION}

4.1. Translatability of English compound words into Indonesian in compound forms

In translating compounds, it can be said to be equivalent if they have the same form both in SL and TL. English compounds can be equivalently translated from English into Indonesian, and some cannot. In this research, researcher found 21 cases of English compounds that can be equivalent translatable into Indonesian in compounds, and 29 English compounds that cannot be equivalently translated into Indonesian counterparts. This part will discuss the findings of equivalent and nonequivalent translation of English compounds into Indonesian found in The Hunger Games.

Equivalent form in translating English compound into Indonesian

After identifying the data based on the English language and Indonesian language compound words, there are some equivalent translations done by the translator. Sentences (1)-(4) show the equivalent translation from close compound in English into open compound in Indonesian.

(1) SL : There's enough light in the bedroom to see them.

TL : Ada cukup cahaya di kamar tidur sehingga aku bisa melihat mereka.

(2) SL :......., carefully wrapped in waterproof covers.

TL : ..... hati-hati dengan pembungkus tahan air.

(3) SL : .... it became his official nickname for me.

TL : ....... maka nama Catnip resmi jadi nama julukanku.

(4) SL : The fish-shaped loaf tinted green with seaweed from District 4.

TL : Roti tawar berbentuk ikan dengan bintik-bintik hijau dari ganggang laut dari Distrik 4.

Sentence (5) shows the equivalent translation from English open compound into open compound in Indonesian. But, there is different structure between SL and TL. The difference occurs in form of the shift of head words. In Indonesian, the word heads are positioned in front of the compounds. But in English, the reverse things happen. The word heads are positioned in the end of the compounds.

(5) SL : ........ in the school yard years ago ...

TL : ..... di halaman sekolah beberapa tahun lalu ......

Some of the translated words from SL have idiomatic meaning in TL as in Sentences (6)-(7) below.

(6) SL : ....... around the woods looking for handouts, ....

TL : ..... selama di hutan menunggu sisa buruanku, ......

(7) SL : Probably the drawers hold any number of nightgowns, but .......

TL : Mungkin di laci-laci kamar tidur ini terdapat banyak gaun tidur, tapi .....

Hyphenated English compound is translated into Indonesian without hyphen as in sentences (8)-(10). There are some words that are compounds in form of hyphenated words in English. In their counterparts, they exist in unhyphenated forms. This is due to the fact that Indonesian does not recognize hyphenated compounds; the hyphen is usually used for repeated words. 
(8) SL : ..., I flatten out on my belly and slide under a two-foot stretch TL : ..... tubuhku ke bawah bagian pagar yang longgar sekitar setengah meter.

(9) SL : ...., middle-aged man, who at this moment appears hollering something........

TL : ...... lelaki gendut setengah baya, yang pada saat ini sedang mengoceh .......

(10) SL : ....., one hand clutching a half-dozen knives.

TL : ...... satu tangannya memegang enam bilah pisau.

Non-equivalent form in translating English compound into Indonesian.

In spite of having the equivalent form, there is also non-equivalent form occurring in translating from the SL to the TL. Sentences (11)-(16) show the nonequivalent translation because the changing form of compounds in SL become single word in TL done by the translator.

(11) SL : He's good-looking, he's strong enough to handle the work in the mines, .......

TL : Dia tampan, cukup kuat untuk bekerja di tambang, ........

(12) SL : Today her drab school outfit has been replaced .........

TL : Hari ini seragam sekolahnya membosankan sudah diganti .......

(13) SL : We ate slices of bread for breakfast and headed to school.

$\mathrm{TL}$ : Kami makan beberapa potong roti untuk sarapan lalu berangkat ke sekolah.

(14) SL : ....... the glistening buildings in a rainbow of hues that tower into the air .......

TL : .... dengan warna-warni pelangi yang menjulang ke angkasa .....

(15) SL : ........, in an abandoned warehouse that once held coal.

$\mathrm{TL}:$...... terdapat di gudang terbengkalai yang dulu jadi tempat penyimpanan batu bara.

(16) SL : She can hit the target every time with a slingshot.

TL : Dia selalu bisa mengenai sasaran dengan katapel.

Not only translated into single word, the changing of compounds are translated into phrase. On the translated forms, they look like compounds in Indonesian, but they are actually phrases in which the elements of the united words can be intervened with words like yang, tidak, sangat, or agak as in sentences (17)(18).

(17) SL : Like a long dream that deteriorated into a nightmare.

TL : Seperti mimpi yang panjang berubah menjadi mimpi buruk.

(18) SL : It's one of the high-speed Capitol models ...........

$\mathrm{TL}$ : Ini salah satu kereta milik Capitol yang berkecepatan tinggi,

Sentences (19)-(20) show the English compound is translated into repetition in Indonesian. Such words already have repetitive forms in nature which if they are about to be broken down into each element from which the single base word is form, they end up in losing their meanings.

(19) SL : The Capitol twinkles like a vast field of fireflies. 
TL : Capitol berkilau berkedip-kedip seperti lapangan yang penuh cahaya kunang-kunang.

(20) SL : ..... but somehow that seems childish.

TL : .... tapi itu bakal terdengar kekanak-kanakan.

\subsection{Factors Triggering the Emergence of Non-Equivalent Forms}

There are at least three prominent factors triggering the emergence of nonequivalent forms in translating English compounds into Indonesian counterparts; they are cultural factor, language change, and style.

4.2.1 Cultural factor

A society comprises a number of people sharing many things in common: their behaviour, collective thoughts, spiritual aspect, language and some others. This is what we can refer to as culture. A certain collection of people might have different culture from another collection of people and it can be obviously seen from the language they use. In linguistics, the Sapir-Whorf Hypothesis states that there are certain thoughts of an individual in one language that cannot be understood by those who live in another language (Leavitt in Jourdan and Tuite, 2006: 70). If a certain concept exists in the culture of the society, there is a lexicon for it in order to enable the people to name it in their life. Therefore if people from different culture want to use the concept, they have to choose either to adapt the original name (by adjusting to the phonotactic rule of the language) or give their own label.

In the case of The Hunger Games translation, there are some English compounds that can be translated into single words Indonesian, for example slingshot translated into katapel. It means that among Indonesian people the concept of slingshot is part of their culture and has its own lexicon. As for English speakers, it's a borrowing concept and to name it, they form a compound (of which it is easier rather than making a certain lexicon to name it).

1) Language change

New words are being formed due to the changing languages. Languages keep changing as a result of development in science and technology. The both factors alter the culture so do they to the language of a current society. New words vary in form as a results of these phenomena namely:

(i) The so called proto-language exist as a base of any derivative languages. Proto-language may contain elements that will be altered by people of current culture in terms of space and time. For instance Latin develops into Portuguese, Spanish, French, Italian, and Romanian.

(ii) Some languages act as preceding languages from which new language develops over time in a particular place. For instance from Latin emerges Greek.

(iii) Absorption and Adaptation. As science and technology keep developing, new things emerge and they might be considered as the never-seen things. People confuse to call them and give name to the things they do see for the first by simply absorb the term from somewhat language which the term comes from or exist. In culture which people have fear of being contaminated by other or new culture, the words undergo adaptations to the existing systems of the cultures (Crowley, 1992: 21-34).

2) Style

Not all of the non-equivalent forms are caused by different culture and language change. For some reasons, it happens due to the style of the author or 
translator. For instance, the author choose to use compound "good-looking" rather than a single word "handsome" and it results in the non-equivalent translation to "tampan" in Indonesian.

Therefore, due to the different culture and nature of language, the emergence of new words is an inevitable fact. In translation, this state will affect the emergence of non-equivalent forms, either in the source or target language. A translator must be able to look for the best forms to deliver the meaning from the source to the target language. In addition, the style in choosing particular word instead of another also takes important part in causing the non-equivalent forms. However, this kind of phenomenon normally occurs and already part of the art of translating since what matters the most in translation if meaning delivery.

\section{CONCLUSION}

According to the result, it can be seen that English compouns are divided into three general forms namely open compound, closed compound, and hyphenated compound. But in Indonesian, compounds merely exist in open form. It means that the words never exist in closed and/or hyphenated words. English compounds are translatable and untranslatable into compounds in Indonesian. The main factor causing the untranslatability is the different culture of SL and TL, language change, and style of the author or translator which primarily affect the translation into target language (TL).

\section{REFERENCES}

Arif, Zulfan. 2015. "The Translation Shift of Compound Nouns in The Great Gatsby's Movie Subtitles". Yogyakarta: S1-Thesis of State Islamic University Kalijaga.

Catford, J.C. 1965. A Linguistic Theory of Translation. Oxford: Oxford University Press.

Creswell, Jhon W. 2014. Fourth Edition Research Design: Qualitative, Quantitative, and Mixed Methods Approaches. Universitas Nebraska, Lincoln: Sage Publications Inc.

Crowley, Terry. 1992. An Introduction to Historical Linguistics. Oxford: Oxford University Press.

Hatim and Munday. 2004. Translation, an Advanced Resource Book. London: Oxford University.

Jourdan, Christine and Kevin Tuite. 2006. Language, Culture and society. USA: Cambridge University Press.

Kantiastuti, Herdani. 2014. "An Analysis of Category Shifts in the EnglishBahasa Indonesia Breaking Dawn Movie Texts. Yogyakarta. S1-Thesis of Yogyakarta State University.

Newmark, Peter. 1988. A Textbook of Translation. U.K: Prentice Hall International Ltd.

Nida, Eugene A. and Charles R. Taber. 1982. The Theory and Practice of Translation. Netherlands. E. J. Brill, Leiden.

Noviana, Norma. 2012. "A Descriptive Analysis of Translation Shift on Stephanie Mayers New Moon and Its Translation". Yogyakarta: S1Thesis of Ahmad Dahlan University.

Purwanti. 2012. "A Noun Phrase Translation Shift Analysis Used in Dan Brown's The Da Vinci Code and its Indonesian Translation Version". Yogyakarta: S1-Thesis of Ahmad Dahlan University. 
Purwarahardi, Meilas. 2014. "The Effects of Rank Shifts on the Characterization of the Main Character in Transformers Movie Texts. Yogyakarta: S1-Thesis of Yogyakarta State University.

Sunarto, Edy. 2015. "A Translation Shift Analysis of Noun Phrase in Subtitling of Ice Age 4 Movie by Sagaz Net". Surakarta: S1-Thesis of Muhammadiyah University of Surakarta. 